\title{
Disector Z-axis mechanical method for stereology
}

\author{
RICARDO XAVIER-VIDAL \\ Associação Xavier-Vidal para Direitos Humanos, Ciência, Tecnologia e Desenvolvimento (AXV) \\ Alameda São Boaventura, 348 (parte), Fonseca, 24120-196 Niterói, RJ, Brasil \\ Manuscript received on November 18, 2008; accepted for publication on November 4, 2009
}

\begin{abstract}
The purpose of this work is to calibrate a not expensive microscope to be applied in Optical Disector estimation. The evaluation of "Z-axis" bias and the "Z-axis" calibration were made utilizing a cover slip and a "manual digimatic outside micrometer scale" (Mitutoyo, Japan). Calibrating the cover slip we performed the calibration of the "Z-axis" of a microscope. In the cover slip two lines were painted with different colors using a pen glass. A blue line was painted on the up surface and another line (red) on the bottom surface of the cover slip forming a cross. Two metal rings with one palette welded in each were adapted in the microscope. Other palette was welded in the gross focuses in order to restrict the route of the fine focuses (Z-axis study) using the two palettes fixed in both rings. Results show that 10 micrometers in "Z-axis" were equal to 3.2 micrometers in the scale of its fine focuses of the microscope. Then, a Disector of $10 \mu \mathrm{m}(10 \mu \mathrm{m}$ in Z-axis $)$ is equal to 3.2 micrometers in the fine focuses of this microscope. In conclusion, "Z-axis" calibration is crucial to assure enough precision for Disector Method since the equipment can be manufactured without the ideal precision or its precision can be lost after use.
\end{abstract}

Key words: stereology, disector, optical disector, morphometry, Z-axis.

\section{INTRODUCTION}

The calibration of a system is crucial to make morphometric evaluations. Concernig morphometric microscopical studies using test-systems in an established area and volume of a tissue, we have to develop special tools, such as, "d" calibration of a system (Weibel 1979) "forbidden line" to avoid overestimation of particles in a specific area (Gundersen 1977, 1978) and in a specific volume, which has been solved using the "Disector Method" (Sterio 1984). Also, the problem of loss of biological structures on the surface of a slice is necessary to be considered (Andersen and Gundersen 1999).

The precision of the Z-axis to perform the Disector Method is really crucial to its use. Nevertheless, concerning the fine focus, the equipment can be manufactured without the ideal precision, or its precision can be lost after use. Simple or sophisticated scientific equipment can be often altered in their precision, so they must be periodically checked.

E-mails: ricardoxv@globo.com
The Stereological Research Laboratory (Aarhus University (AU), Denmark) developed the Olympus Denmark C.A.S.T. - Grid System. This system can be considered the best system for Stereological quantification. However, this system is extremely expensive to small and modest laboratories in many parts of the globe. Thus, here we propose a simple low cost and precise method to allow the use of Optical Disector Method in every small laboratories of the word.

Our goal was to calibrate a not expensive microscope in order to be applied in Optical Disector estimation. This use in cheap microscope will help all laboratories to get into the Stereology world and mainly in the world of Disector.

\section{MATERIALS AND METHODS}

An old fashioned microscope was utilized to evaluate the "Z-axis" bias. The "Z-axis" calibration was performed using a cover slip. The thickness of a cover slip was considered for the "Z-axis" calibration. The central region 
of a cover slip was utilized to calibrate the "Z-axis" using a "manual digimatic outside micrometer scale" (Mitutoyo, Japan). The ideal precision is $0.001 \mathrm{~mm}(1 \mu \mathrm{m})$. In the central region of the cover slip, two lines were painted with different colors using a pen glass. A blue line was painted on the up surface and another line (red) on the bottom surface of the cover slip forming a cross. Two metal rings with one palette welded in each were welded in the microscope. One other palette was welded in the gross focuses in order to restrict the route of the fine focuses (Z-axis study) using the two palettes fixed in both rings (Figs. 1 and 3). Note that palettes welded in the rings bump into the palette welded in the gross focuses, but the palettes welded in the rings can also pass by the palette welded in the gross focuses (after bumping it) to better visualize the biological tissue (Figs. 1D and $\mathrm{E}$ ).

\section{RESULTS}

Using the "manual digimatic outside micrometer scale" (Mitutoyo, Japan), we found the thickness of $0.160 \mathrm{~mm}$ $(160 \mu \mathrm{m})$, from the superior surface of the superior line (blue) painted on the cover slip to the inferior surface of the cover slip (without painting the red line). The inferior surface of the cover slip was not painted (red line) in this procedure because, in the following procedure, we also used de superior surface (tight to the glass) of this inferior line painted on the bottom surface of the cover slip in order to calibrate the $\mathrm{Z}$-axis.

After this, it was necessary to check out the fine focuses scale of the microscope, the Z-axis distance from the superior surface of the superior line painted on the cover slip to the superior surface (tight to the glass) of the inferior line painted on the bottom surface of the cover slip as said before. In our microscope, we found this distance equal to 51 micrometers (Fig. 2). The scale of the fine focuses in our microscope was 50 micrometers (which means a rout of 360 degrees in fine focuses).

Then, it should be made a quite simple calculation in order to identify the distance of the adapted palettes welded in the rings fixed in the fine focuses to be used for the Disector Method (Fig. 1C and Fig. 3).

$$
\begin{gathered}
160 \mu \mathrm{m}-100 \% \\
51 \mu \mathrm{m}-\quad \mathrm{X}
\end{gathered}
$$

$X=\frac{5100}{160}=31.875 \mu \mathrm{m}$ in the fine focuses of the microscope $=100 \mu \mathrm{m}$ in Z-axis.

Then, an unusual Disector of $100 \mu \mathrm{m}$ means $31.875 \mu \mathrm{m}$ in the fine focuses of the microscope.

For instance, an usual Disector of $10 \mu \mathrm{m}$ means $31.875 / 10=3.1875$ in the fine focuses of the microscope.

One way of finding, for instance, the value of $10 \mu \mathrm{m}$ (for a Disector of $10 \mu \mathrm{m}$ ) in the fine focuses of the microscope is to divide 51 per 16 , finding the same 3.1875. The value of $20 \mu \mathrm{m}$ (for a Disector of $20 \mu \mathrm{m}$ ) in the fine focuses of the microscope is to divide 51 per 8 , finding 6.375 .

But the simplest way of finding the equivalent value of $1 \mu \mathrm{m}$ in the $\mathrm{Z}$-axis of the microscope is to divide 51 per 160 , finding 0.31875 . So, $1 \mu \mathrm{m}$ in the $Z$-axis is equal to 0.31875 in fine focuses of the microscope. Then, this value can be multiplied to find the value of the Disector to be used (for instance, a Disector of $10 \mu \mathrm{m}$, a Disector of $15 \mu \mathrm{m}$, a Disector of $20 \mu \mathrm{m}$, or a Disector of other dimension).

This means that $3.2 \mu \mathrm{m}$ in the fine focuses of the microscope is equal to $10 \mu \mathrm{m}$ in Z-axis of the microscope because fine focuses of the microscope lost their precision or were not manufactured with the ideal accuracy. Then, a distance of 10 micrometers in the Zaxis of this microscope is equal to 3.2 in the scale of its fine focuses.

Now the fine focuses of the microscope will have to be positioned with a distance of 3.2 from one palette to the other palette fixed in the two metal rings (Fig. 3).

\section{DISCUSSION}

In Stereology, we had to solve several problems of calibration of the equipment as the "d" calibration of a system (Weibel 1979), the "forbidden line" to avoid overestimation of particles in a specific area (Gundersen 1977, 1978, 1981), and also in a specific volume (Disector Method) (Sterio 1984, Gundersen 1986). For the development of the Disector Method, it was compulsory to consider the exclusion of certain particles in the area to avoid over-estimation, and the current easier, simpler and safe method is the "Forbidden Line" (Gundersen 1977, 1978, 1981). As a matter of fact, in Disector we have to previously define an arbitrary "Forbidden 


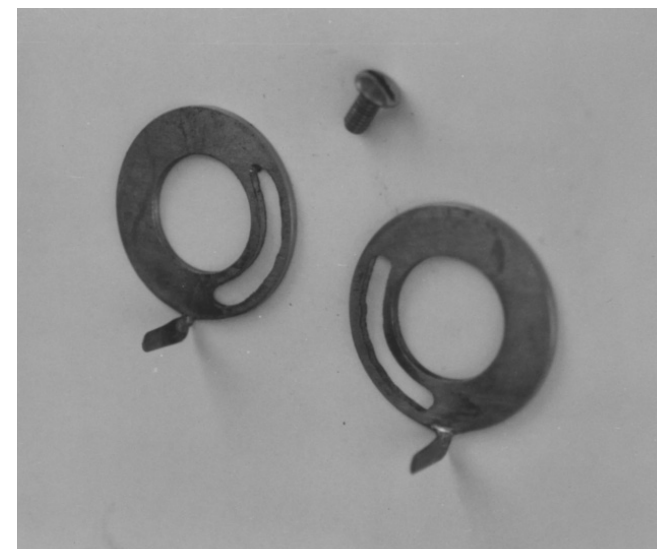

(A)

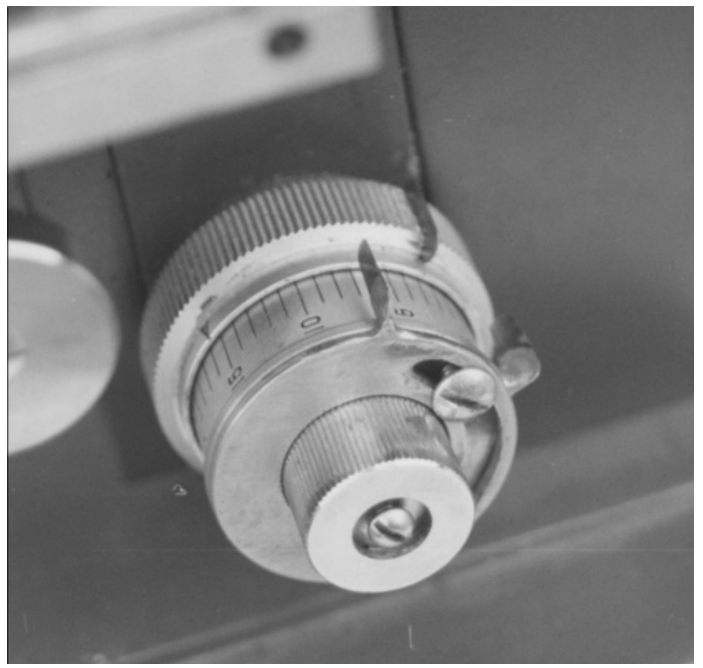

(C)

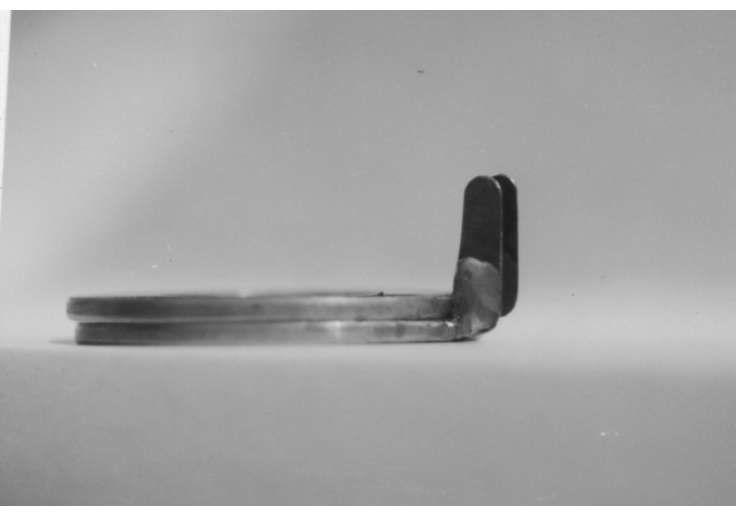

(B)

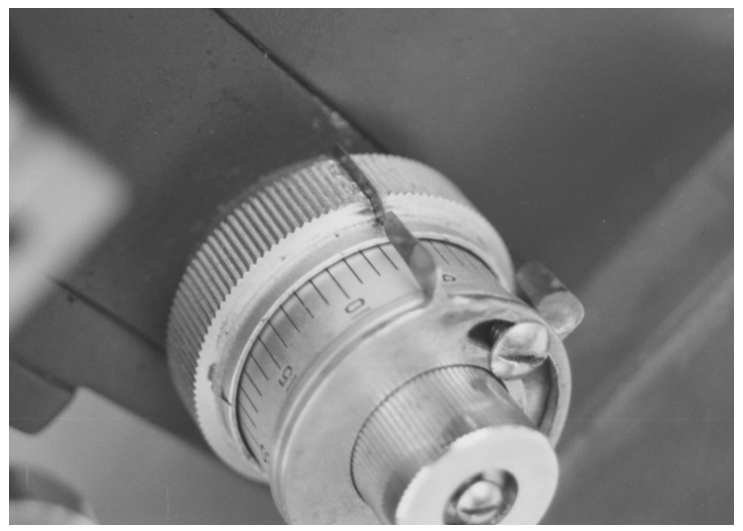

(D)

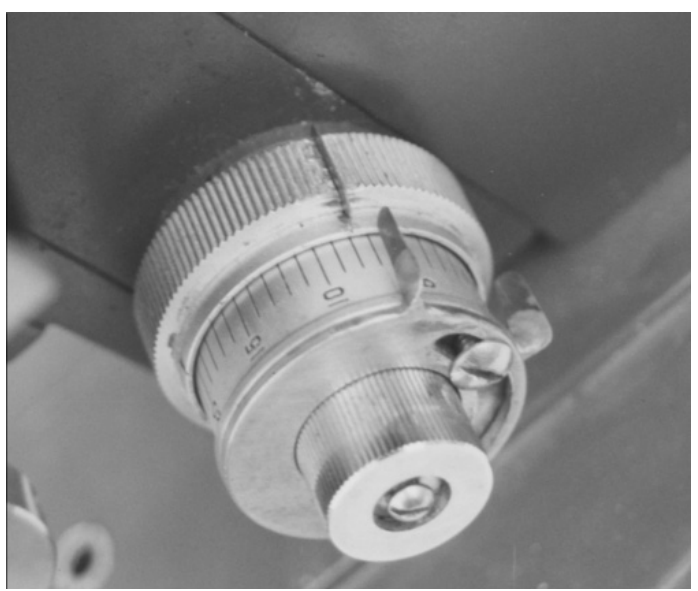

(E)

Fig. 1 - The two rings of metal with one palette welded in each (A-E) and the palette welded in the gross focuses (C-E) to restrict the route of fine focuses (Z-axis study) (D). Note that palettes welded in the rings, bump into the palette welded in the gross focuses, but the palettes welded in the rings can also pass by the palette welded in the gross focuses (after bump it) to better visualize the biological tissue (D-E). 


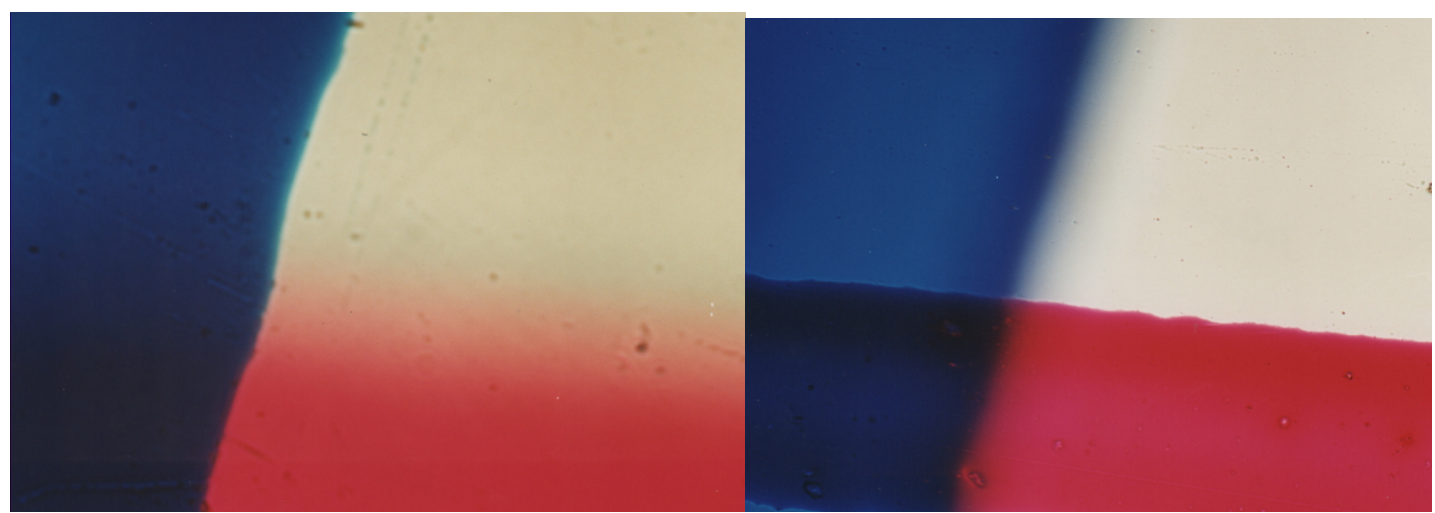

(A)

(B)

Fig. 2 - Microscopic visualization of a cover slip. In the central region of the cover slip, two lines were painted with different colors using a pen glass. A blue line (A) was painted on the up surface and another line (red) (B) on the bottom surface of the cover slip forming a cross. Using the "manual digimatic outside micrometer scale" (Mitutoyo, Japan), we found the thickness of $0.160 \mathrm{~mm}(160 \mu \mathrm{m})$, from the superior surface of the superior line (blue) painted on the cover slip to the inferior surface of the cover slip (without painting the red line). The inferior surface of the cover slip was not painted (red line) in this procedure because, in the following procedure, we also used the superior surface of this inferior line painted on the bottom of the cover slip (tight to the glass) in order to calibrate the Z-axis. After this, it was necessary to check out the fine focuses scale of the microscope, the Z-axis distance from the superior surface of the superior line painted on the cover slip to the superior surface (tight to the glass) of the inferior line painted on the bottom surface of the cover slip as said before. In our microscope, we found this distance equal to 51 micrometers (Fig. 2). The scale of the fine focuses in our microscope was 50 micrometers (which means a rout of 360 degrees in fine focuses).

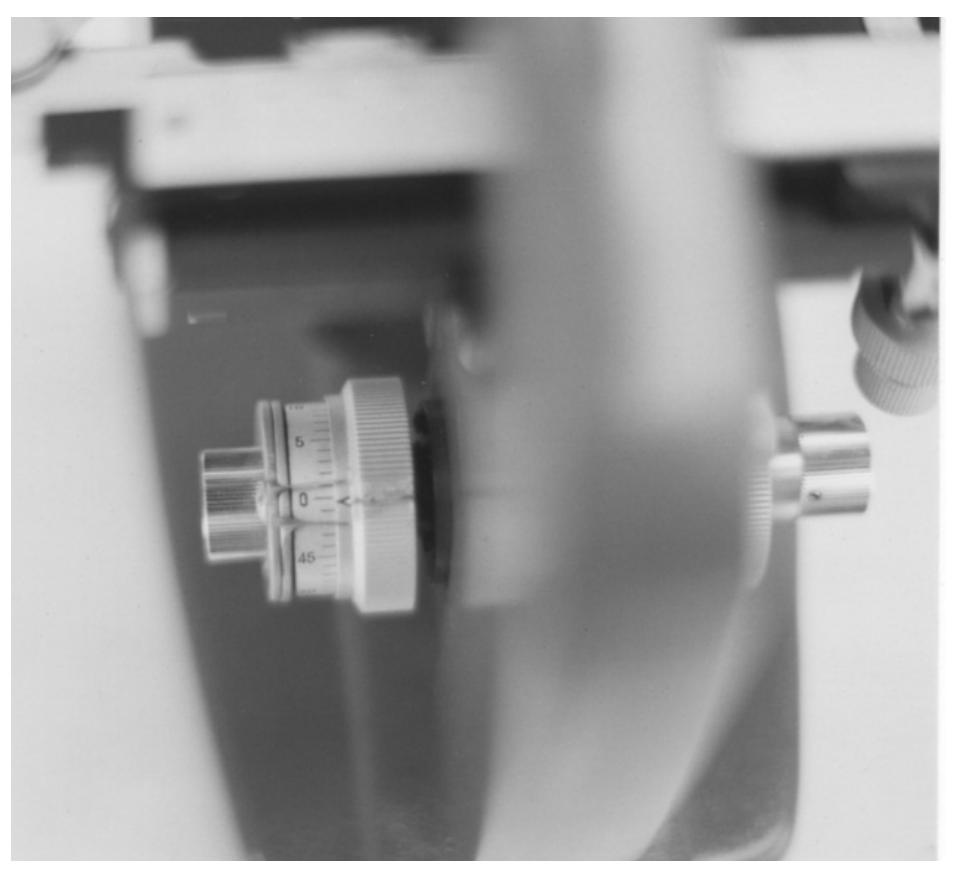

Fig. 3 - The correct position of the palettes welded in the rings of our microscope. The distance from one palette to the other was estimated as 3.2 marks $(\mu \mathrm{m})$ of the fine focuses, means $10 \mu \mathrm{m}$ in Z-axis of the microscope (Optical Disector of $10 \mu \mathrm{m}$ ). 
Z-Plane" that have to be chosen between two planes of an Optical or Physical Disector $\left(\mathrm{Q}^{-}\right.$or $\mathrm{Q}^{+}$plane) within arbitrary distance depending on the tissue studied. We also have to consider the thickness of the slice to avoid the problem of loss of biological structures on the surface of a histological section (Andersen and Gundersen 1999). In Disector, the particle touching the previously established "Forbidden Z-plane" must be excluded. Like the "Forbidden Line", then, Disector could also be called "Forbidden Plane" or "Forbidden Z-plane". Some other methods of excluding particles in the area do not have this same characteristic of having "Forbidden Lines", neither the possibility of thinking about the existence of a "Forbidden Plane" or "Forbidden Z-plane" (Sterio 1984, Gundersen 1986). The elaborator of the Disector (Sterio 1984) ("Forbidden Plane" or "Forbidden Z-Plane") had a profound knowledge of the "Forbidden Line" (Gundersen 1977, 1978, 1981).

Here we utilized a cover slip to calibrate the "Z-axis" of a not expensive old monocular microscope. Other option, more expensive, to calibrate the "Z-axis" fine focus of a microscope is the use of small spheres of a known diameter, for instance, micro-spheres with a diameter of $10 \mu \mathrm{m}$ (standard deviation $=0.08 \mu \mathrm{m}$, coefficient of variation $=0.8 \%)($ Electron Microscopy Sciences, USA). Nevertheless, it costs about US\$275,00 (plus freight about US\$40,00).

The Olympus Denmark C.A.S.T. - Grid System, which we consider to be the best system to biological quantifications for Stereology, costs approximately 50.000 USD, which is very expensive to small and modest laboratories. Because of this, we aimed to develop a very simple procedure to calibrate and utilize microscopes to perform Optical Disector Method to permit all laboratories of the globe to enter in the world of Disector Method of quantification (Gundersen et al. 1988a, b, Nyengaard and Gundersen 1992, Xavier-Vidal and Madi 1999, Xavier-Vidal 2000, 2006, Xavier-Vidal et al. 2004, 2006).

\section{ACKNOWLEDGMENTS}

The author acknowledges so much his Lord and God Jesus Christ. The author wishes to thank Prof. Doctor Hans Jorgen G. Gundersen for his suggestion to use the "manual digimatic outside micrometer scale" to mea- sure the thinking of the cover slips, and for his incentive and friendship; Prof. Doctor Jens R. Nyengaard (Stereological Research Laboratory, Aarhus Universitet (AU), Denmark), Prof. Doctor Luiz Querino de Araújo Caldas (Universidade Federal Fluminense (UFF), Brazil) and Prof. Doctor Bertoldo Klinger Machado (Universidade Santa Úrsula (USU), Brazil), for their incentive and friendship; his student Prof. Luiz Roberto Mendes Barboza, for his questions and incentive; the author also acknowledges, his father José Vandir Jorge Vidal (in Memoriam) and his mother Marina Xavier Vidal for their incentive and support. During this work, the author had a PhD Grant from Coordenação de Aperfeiçoamento de Pessoal de Nível Superior (CAPES) - Brasília, Brazil. The Xavier-Vidal Association acknowledges the Faculdade Maria Thereza (FAMATh, Brazil) for the donation of the old fashion microscope here utilized. The English revision of this article was performed by Mayara Vidal Carneiro.

\section{RESUMO}

O propósito deste trabalho é a Calibração de um microscópio comum de baixo custo de forma a usá-lo para estimativas do Método Disector Óptico. A avaliação do viés e a calibração do "eixo-Z" foram feitas usando uma lamínula e um "micrômetro manual digital" (Mitutoyo, Japan). Com a calibração da lamínula, calibramos o "eixo-Z” de um microscópio. Foram pintadas duas linhas com diferentes cores utilizando canetas para vidro. Uma linha (azul) foi pintada na superfície superior da lamínula e outra linha (vermelha) foi pintada na superfície inferior da lamínula, formando uma cruz. Dois anéis de metal com uma paleta de metal soldada a cada um deles foram adaptados ao micrométrico do microscópio. Outra paleta foi soldada ao macrométrico do mesmo microscópio, o que foi feito de forma a limitar o percurso do micrométrico (eixo-Z) pela ação desta em conjunto com a ação das duas paletas fixadas no micrométrico. Os resultados mostraram que 10 micrômetros no "eixo-Z" do microscópio foi igual a 3,2 na escala do seu micrométrico. Assim, um Disector de $10 \mu \mathrm{m}$ ( $10 \mu \mathrm{m}$ no eixo-Z) é igual a 3,2 micrômetros no micrométrico do microscópio utilizado. Concluindo, a calibração do eixo-Z é crucial para assegurar a precisão suficiente para as avaliações usando o Método Disector, já que os equipamentos podem ser manufaturados sem a precisão ideal ou podem perder sua precisão durante o tempo com o uso. 
Palavras-chave: estereologia, disector, disector óptico, morfometria, eixo-Z.

\section{REFERENCES}

Andersen BB And Gundersen HJG. 1999. Pronunced loss of cell nuclei and anisotropic deformation of thick sections. J Microsc 196: 69-73.

GUNDERSEN HJG. 1977. Notes on the estimation of numerical density of arbitrary profiles: the edge effect. J Microsc 111: 219-223.

GUNDERSEN HJG. 1978. Estimators of the number of objects per area unbiased by edge effects. Microsc Acta 81: 107-117.

GUNDERSEN HJG. 1981. Stereologi; Eller hvordan tal for rumlig form og indhold opnas ved iagttagelese af strukturer pa snitplaner. Kobenhavn: Laegeforeningens Forlag.

GUNDERSEN HJG. 1986. Stereology of arbitrary particles. A review of unbiased number and size estimators and the presentation of some new ones, in memory of William R. Thompson. J Microsc 143: 3-45.

Gundersen HJG ET AL. 1988a. Some new, simple and efficient stereological methods and their use in pathological research and diagnosis. APMIS 96: 379-394.

Gundersen HJG ET AL. 1988b. The new stereological tools: disector, fractionator, nucleator, and point sampled intercepts and their use in pathological research and diagnosis. APMIS 96: 857-881.

NyENGAARD JR AND GUNDERSEN HJG. 1992. The isector: a simple and direct method for generating isotropic, uniform random sections for specimens. J Microsc 165(3): $427-431$.
STERIO DC. 1984. The unbiased estimation of number and sizes of arbitrary particles using the disector. J Microsc 134: $127-136$.

WeIBEL ER. 1979. Stereological methods. vol.1: practical methods for biological morphometry. New York, Academic Press.

XAVIER-VIDAL R. 2000. Avaliação morfológica, à microscopia óptica convencional, do miocárdio ventricular de ratos Wistar submetidos ao bloqueio sistêmico da síntese do óxido nítrico. Rio de Janeiro, RJ, Universidade Federal do Rio de Janeiro (D.Sc. Dissertation).

XAVIER-VIDAL R. 2006. O Método Estereológico dirigido aos estudos Biológicos e Biomédicos; Teoria e Prática com uso do Modelo Experimental L-NAME de bloqueio sistêmico da síntese do óxido nítrico. Braz J Investig Pathol Morphol Morphom 1(3): 30-53. Available at: www.xavier-vidal.org.br.

XAVIER-VIDAL R AND MADi K. 1999. Comparison between Right and Left Ventricular Myocardia during the Human Fetal Period. Stereological Evaluation. Arq Bras Cardiol 72(5): 587-592.

XAVIER-VIDAL R ET AL. 2004. Multivariate Allometry and myocardium abnormalities during experimental systemic nitric oxide blockage. J Brasil Patol Med Lab 40(3): 203208.

XAVIER-VidAL R ET AL. 2006. Multivariate Allometry Using Stereological Data Belongs From L-NAME Induces Hypertension, Cardiac Hypertrophy and Stereological Myocardim Lesions (day 35). Braz J Investig Pathol Morphol Morphom 1: 7-14. Available at: www.xavier-vidal.org.br. 